\title{
Human Beings after Catastrophe: Poetical Portraits by Primo Levi and Tamiki Hara
}

\author{
Veronica De Pieri
}

Alma Mater Studiorum University of Bologna

\section{Introduction}

The representability of collective trauma has been a demanding challenge since the occurrence of the two major atrocities of the twentieth century: The deportation and the extermination of Jews and other minorities in the Nazi concentration camps, and the atomic bombings of Hiroshima and Nagasaki by the US on August 6-9, I945.

The legitimacy of artistically representing human annihilation is far from being a solved issue. It has rather encouraged the collaboration of academics in the attempt to shed some light on the events: Historians have been committed to the collection of historical data; psychologists have made efforts in approaching survivors to help victims in acting out and working through the traumatic experience they witnessed (LaCapra, 200I, p. 64); literary critics have animated the discussion about the aesthetic value of the literary responses to the topic. ${ }^{\text {I Eventually, the so- }}$ called "trauma study" field born in the US in the I990s, especially thanks to the contributions by Cathy Caruth, can be addressed as a great achievement in converging this multidisciplinary perspective on trauma narratives. Actually, the investigation of testimonial accounts became crucial on two fronts: On the one hand,

I Works by Sidra DeKoven Ezrahi, Robert Jay Lifton, van der Kolk, John Whittier Treat and Tachibana Reiko are worth to mention.

How to cite this book chapter:

De Pieri, V. 202 I. Human Beings after Catastrophe: Poetical Portraits by Primo Levi and Tamiki Hara. In: Jonsson, H., Berg, L., Edfeldt, C. and Jansson, B. G. (eds.) Narratives Crossing Borders: The Dynamics of Cultural Interaction. Pp. 99-I 20. Stockholm: Stockholm University Press. DOI: https://doi.org/Io.I6993/bbj.e. License: CC-BY 4.0 
the appeal for a collective understanding of the historical events was at the basis of the cultural memory formation. This was considered an essential step in order to enhance the recovery of the national governments after the war. On the other hand, it was at the core of the re-construction of survivor's identity, disrupted by the horrors of the war which reached an unbelievable, massive scale.

Although historical research was mainly interested in the historical reliability of the testimonial accounts, psychology proved that the scriptotherapy (therapeutical writing, LaCapra's “confessional literature"; Dayton, 2000, p. I 8) was an effective means to activate the process of healing from trauma and to recover self-identity by keeping journals and diaries. The search for meaning regarding the human massacres set in motion the quest for a missing link, a form of "history-telling that includes both the voice of the historian and the memory of survivors" (Young, 2003 , p. 277-278), in other words, a literary production that well combines historical data and survivors' testimonies. Obviously, this pursuit raised questions about the literary value of the writings thus casting doubts on the fictionality approach to represent catastrophes such as the Shoah and the atomic bombings.

The controversy revolved around the aesthetic transposition into words of survivors' struggles. Based on the assumption that a new language was necessary to express both Shoah and atomic bombing experiences, any rhetorical, stylistic, artistic embellishment in order to convey the unspeakable contributes to make it more accessible to a wider public, and even more acceptable, thus, comprehensible. To domesticate the atrocity was argued by some survivors - and by some critics too - as disrespectful because it implies the devaluation of victims' painful memories, suffering and loss. To make the trauma of Auschwitz and Hiroshima and Nagasaki acceptable also means to turn it into a tolerable, even justifiable barbarity. Finally, to try to subdue those experiences to literary production also implies its understanding: An unachievable task for the traumatic scale those catastrophes entailed.

In this context Theodor W. Adorno stated his famous quote: "Nach Auschwitz ein Gedicht zu schreiben, ist barbarisch" (Adorno, I955, p. 30) which additionally encouraged the literary 
domain to discuss the legitimacy of fictional representations of the catastrophic event and its aftermath, or its effects on the traumatized victims. It is not by mere chance that the Japanese genbaku bungaku 原爆文学 (“literature of the atomic bombings") was firstly refused by the Japanese establishment and by the hibakusha ${ }^{2}$ themselves, sounding a critical note for the literary value of the fictionalized works on the theme. Although works on this particular topic have been rediscovered soon after the Fukushima nuclear accident, they still cannot be found easily on bookstores' shelves.

What these considerations underline, is their intrinsic connection with the ethics of the disaster, that is, the ethical implications beyond a public discourse about survivors' suffering. Aesthetics and ethics came to the fore as the keywords in the cultural narrative on Shoah and atomic bombing topics and continue to fuel the critical debate even nowadays.

This brief study is focused on two authors, namely, Primo Levi and Tamiki Hara, who are very prolific in their literary experimentations, both in prose and poetry. The study turns the attention to two poems, Levi's Se questo è un uomo and Hara's Kore ga ningen na no desu, which rose from the ashes of the Nazi concentration camps and the atomic bombing of Hiroshima, respectively. The aim is to stress the analogies, rather than the differences, between these poetic works, in an attempt to demonstrate how similar responses to trauma can be detached regardless of territorial, cultural and stylistic boundaries. Hence, the testimonial narrative turns out to convey a universal language that unifies, rather than divides, human beings in the wake of catastrophes.

I should make some remarks about the terminology that usually denotes these events. Both tragedies are addressed by the inaccurate use of the term genocide, which obviously intends to stress the scale of the disaster according to the number of victims. Critics highly disagree about the number of victims of the Nazi's Final Solution plan, that nowadays is estimated to be

2 Victims exposed to atomic bombing radiations. After Fukushima Daichi Nuclear Power Plant accident of March II, 20II, this label was also used for victims exposed to radioactivity, although different characters are used for the words in Japanese (被爆者 for the former, 被曝者 for the latter). 
somewhere in between 6 and II millions of deportees, ${ }^{3}$ while a total of $130-226$ thousand victims are estimated to have been decimated by nuclear weapons. ${ }^{4}$ The term genocide, firstly used by Raphael Lemkin to denounce the Armenian extermination by the Ottomans (I9I4-I923) was accepted and adopted by the UN to define the premeditated plan to annihilate a group of people for their particular nationality, ethnicity, race or religion (Lemkin, I946). This is obviously not the case for the hibakusha victims, who are simply referred to as "casualties of war," thus devaluating the civilian role in the catastrophe. As for the Holocaust, it remains perhaps the most common term in the collective imagination, since it is generally used by historians as the appellation corresponding to Shoah, at least from the end of World War II. Its usage is still inappropriate due to its religious meaning and references to the Old Testament, especially to the religious service during which the victim - usually animals - is offered to pay tribute to God. This meaning adds totally dissenting connotations to the historical facts, negatively influencing the definition of the event. Nevertheless, some literary critics still address the literary production on the theme as "Holocaust literature" or "Holocaust novel." For the above-mentioned reasons I support those scholars who prefer the use of Shoah, which in Hebrew means (simply) "very big catastrophe." It should be noticed, however, that, due to its Hebrew origin, this appellative can be confused as referring only to the extermination of Jews, as is, actually, the employment of the words "Final Solution," which was a secret military scheme reserved only to Jews (Angress, W. T. et al., 2002). All in all, in my research, I usually use Shoah as a term to refer to the annihilation of

3 I suggest checking the site 70.Auschwitz.org, which was created for the 7oth anniversary of the liberation of Auschwitz. A detailed article about the ethnic origins and number of victims can be found at the following link: http://70.auschwitz.org/index.php?option=com_content \& 2 view=article \&id=89:nationality-and-number-of-victims-of-auschwitz \&catid=I I : english-content \&Itemid = I 73 \&lang=en, $2017 / 06 / 25$.

${ }^{4}$ It is worthy of mention that this estimate does not include the high number of survivors who died after the bombing due to the symptoms of the genbakushō. Detailed info at AtomicArchive.com site, link: http://www .atomicarchive.com/Docs/MED/med_chpio.shtml, 20I7/06/25. 
both Jews and other minorities, among which were homosexuals, gypsies and political prisoners in the Nazi extermination camps.

\section{Primo Levi, Se questo è un uomo}

Soon after the end of World War II, the literary field contributed to a massive production of testimonial and critical works on the theme of the concentration camps in an attempt to reveal and explain the true meaning of the Nazi's Final Solution program. ${ }^{5}$ Differing points of view among victims and scholars contributed to a climate of confusion and fueled the debate around the responsibilities in the extermination program; those concerns were then addressed during the Nuremberg Trials (November 20, I945 - October I, I946). ${ }^{6}$ In this context, the Italian Primo Levi (Turin, July, 3 I, I9I9 - April, I I, I987) distinguished himself for his clear-headed testimonial accounts, which turned him into a firstline spokesperson for the victims of the Nazi Shoah; his literary production provides food for thought about the fundamental role of testimonies and the particular stance words take as a literary means to fight against oblivion.

The celebrated autobiographical work Se questo è un uomo ("If this is a man," I947) was published for the first time only two years after Levi's release from the Monowitz concentration camp, a satellite camp belonging to the wider Auschwitz complex. Although it may be considered the most famous work by the author, Se questo è un uomo is only one among the many publications that Levi dedicated to the topic of Shoah in his commitment to bear testimony to the Nazi's persecution.

From lapsed Hebrew origins, Levi was deported to Monowitz at the end of 1943 , after being arrested for helping a partisan group settled in Val d'Aosta; the author also served a brief time of five days in the Carpi-Fossoli camp before his final deportation to Poland (Segre, I976, p. I85).

5 For a detailed historical explanation about this Nazi politic measure, please check again the USHMM at the following link: https://www .ushmm.org/wlc/en/article.php? ModuleId=I0005 I 5 I, 20I $7 / 06 / 25$.

${ }_{6} \mathrm{Ibid}$. at the link: https:/www.ushmm.org/outreach/en/article.php? ModuleId= I0007722, $2017 / 06.25$. 
The author's concern for the value of testimony shines clearly through the poem chosen as overture of his documentary novel. No particular name is given to the verses, which are likely to belong directly to the testimonial account of the deportation, as confirmed by the fact that the poem was written in January, Io, I946, during the completion of Se questo è un uomo's drafting (Segre, I976):

You, who live safely

In your warm houses,

You, who find, coming back in the evening

Hot food and friendly faces:

Consider if this is a man

Who works in the mud

Who does not know peace

Who fights for a scrap of bread

Who dies for one "YES" or "NO".

Consider if this is a woman,

Without hair and without name

With no more strength to remember,

Her eyes empty and her womb cold

Like a frog during winter.

Meditate that this came about:

I commend you these words.

Carve them in your hearts

At home, along the streets,

Going to bed, waking up;

Repeat them to your children,

Or may your house fall apart,

May illness inhibit you,

May your children turn their faces from you. ${ }^{7}$

7 Voi che vivete sicuri / nelle vostre tiepide case, / voi che trovate tornando a sera / il cibo caldo e visi amici: /Considerate se questo e' un uomo / che lavora nel fango / che non conosce pace / che lotta per mezzo pane / che muore per un si o per un no. / Considerate se questa e' una donna, / senza capelli e senza nome / senza più forza di ricordare / vuoti gli occhi e freddo il grembo / come una rana d'inverno. / Meditate che questo e' stato: / vi comando queste parole. / Scolpitele nel vostro cuore / stando in casa andando per via, / coricandovi, alzandovi. / Ripetetele ai vostri figli. / O vi si sfaccia la casa, / la malattia vi impedisca, / i vostri nati torcano il viso da voi. Translation is mine, from the original Italian. Please, take 
The poem was published ex-post in the poetical collection entitled L'osteria di Brema ("The Brema Tavern," I975) under the new title of Shemà, which sheds new light on the original version. ${ }^{8}$

Actually, at a first glance, the poem looks like the response of an Häftling (camp inmate) to the greeting message at the entrance of Auschwitz camp, the deceitful "Arbeit macht frei" ("Work makes you free") that became a world-famous emblem of the camouflaged Nazi's "Final Solution" program. Levi bids welcome to the reader to his own concentration camp - his own Inferno, as the article will show later - and the gravity of the words chosen reflect the scale of authorial experience to the extent that the poem serves as the epigraph of the literary account. Both the Nazi's and Levi's messages demand the reader to take action: In the case of "Arbeit macht frei" the intimation is evident: work or die. Levi, true to his literary predisposition, predicts a catastrophic future for those who avoid the imperative to testify about the Shoah experience.

This speculation was born from the new title of the poem shemà - which represents the Hebrew prayer very close to the act of faith; its final verses urge to remember and perpetuate the very meaning of faith itself to the next generations: "these words / Carve them in your hearts / At home, along the streets / Going to bed, waking up," these verses are faithful to the quote of the original Hebrew oration (Segre, I976, p. I 85 ).

A more technical analysis reveals authorial familiarity with literary devices like alliterations, similitudes and chiasmus, all typical stratagems of the art of poetry. Notwithstanding, the poem presents a free verse with no rhymes, a stylistic solution that enables Levi to express himself openly without forcing his thoughts into a strict fixed format. Moreover, the choice of avoiding rhymes helps the readers to focus their minds on the message conveyed by the verses, without losing attention in the rhythmic repetitions of sounds. Alliterations, then, function as the reiterations of the same words, thus resulting in reinforcing the sense of the

note that all the translations used in this article are to be considered as mine, unless otherwise specified.

${ }^{8}$ Please take note that Shemà is also the title used by Desmond Graham in his collection of international poetry after WWII. See Desmond, I998. 
poem, especially in the central verses (vv. 5-I4) where the author describes the appearance of a man and a woman in a concentration camp (five verses each). The symmetry, which appears accurately constructed, can be interpreted as the attempt to restore equal dignity to both genders, both victims of an offence intended to dehumanize the personhood, undermine the identity, annihilate the individual. The chiasmus in the verse "Her eyes empty and her womb cold" (v. I3) is underlined by the similitude of the following verse, which depicts women at the camp like a pond frog: Glabrous, with very prominent eye sockets, thus drawing away from the classic ideal of feminine fecundity.

The first verses of the poem point out the receivers Levi chose for his message. The author does not pour out his hatred and resentment to Nazi persecutors but rather addresses his readers directly. He is talking to everybody who, by keeping in silence those atrocities, become guilty as much as the perpetrators. The implication is significant: Levi's universal monito (warning) finally asks the question about everybody's responsibility towards the Shoah.

For similar reasons, the final verses of the poem that I have earlier classified as Levi's prediction for the readers' future, can rather be interpreted as an authorial admonition. The author is not the powerless observer of the destruction of the reader's house, nor the one who assists disarmed to a hopeless disease, neither the silent counsellor of broken family-ties; Levi is rather the active formulator of those curses. Although its outstanding scale, it is exactly a curse that Levi is spelling out toward the readers in case they deny the Shoah's occurrence. The meaning is powerful: even though readers are supposed not to be directly involved in the persecution and deportation of millions of victims to the death camps, they can be blamed for it, if they pretend to ignore the truth or help with their incredulity to obliterate the facts. The author wishes a future of poverty, illness, and isolation for those guilty of this offence, a destiny that for some reason appears worse than death. The verse: "I commend you these words" (v. I6) echoes the series of imperative clauses: Consider (twice), Meditate, Carve, Repeat. They are the prelude of the final spell which strikes only those who do not respond to Levi's imperative and on the contrary contribute with their attitude to obliterate history. 
This critical analysis aside, further considerations should be addressed toward the role of memory in Levi's production. In the appendix of a school edition of Se questo è un uomo published for the first time in I976, the author explained:

For these survivors to remember is a must: they don't want to forget, and moreover they don't want the world to forget about them, because they know their experience was not meaningless, and that Lagers weren't an incident, unexpected in History. (Levi, I976, p. I66)

Levi's statement casts doubts also on the ethical implications that the testimony entails: The perpetuation of memory shall be a responsibility of both victims and spectators - in Levi's case, his readers. As we have seen in different ways until now, in the authorial perspective this is not a mere advice but rather a moral imperative. Testimony - in any form, oral or written - is the fundamental path to follow in order to keep the memory alive, even for future generations.

There is also another thought-provoking allusion in Levi's comment: The Shoah experience was not meaningless. Its occurrence does have to represent something, even though human beings are not supposed to understand its value. In Se questo è un uomo the author wisely comprehends that "our wisdom was not trying to understand," words that mirror the Nazi Kommando's "-Hier ist kein Warum,-" ("There's no 'why' here”) and his inmates "Ne pas chercher à comprendre" ("Don't try to understand").

Back to the poem, the verse "Who dies for one "YES" or "NO" (v. 9) reflects the image that the Lager's life was established by chance: Illogical motivations and random decisions by the Sonderkommando, the special working units at the camps, constituted by selected Häftlinge who were asked to decide for the life and the death of the other inmates.

Levi seems to remark that eventually, to not be able to understand is not wrong: Humans actually cannot pretend to comprehend the horror of the Shoah. In the Appendix to the testimonial account the author declares:

Maybe what happened can't be understood, on the contrary, it doesn't have to be understood, because to comprehend almost 
means to justify. [...] If understanding is impossible, knowing is necessary, because it happened therefore it can happen again, consciences can be seduced and obscured again: even ours. (Levi, I976, p. I75)

Literature then becomes a useful way to convey testimony: The writing puts memories on paper both preserving them from oblivion and creating a documentary archive of historical data. "Memory as need and duty" adds Segre in the afterward to Se questo è un uomo (1976, p. I85) a task that even the most careless reader should take command of.

I began this investigation on the overture poem of Se questo $\grave{e}$ un uomo by giving an interpretation of the authorial decision to open his documentary account with the poem. The comparison with the "Arbeit macht frei" message reveals Levi's attempt to welcome the readers to the reading of the novel, without making them comfortable. Actually, Levi's poem has nothing to do with the classical lyricism traditionally associated with poetic production: there are no reference to idyllic places, seasonal changes, love affairs, all literary topoi typical - although not unique - of poetry. On the contrary, the effect provokes in the reader discomfort and pain: the same feelings Dante should have perceived in his encounter with Inferno's door: “Abandon all hope - Ye Who Enter Here" (Dante, I32 I, v.9). This message seems to reflect the Nazi's "Arbeit macht frei." Levi's poem can be compared to the doors of Inferno: One-way, everlasting, hopelessness. And even though readers can approach the camp only through a literary journey, thus preserving them from a real death, Levi seems to allude to the soul's death: the testimonial power of Se questo è un uomo affects the readers who cannot remain unperturbed.

The familiarity of the author with literature, which clearly shines through the verses of the poetry in the skillful usage of poetic and rhetoric devices, does not surprise his readers: it is not for a mere chance that Se questo è un nomo is addressed by many critics as a metaphor of Dante's Inferno, the already mentioned Segre in primis; an allegory ingeniously constructed through many references to the Divine Comedy in the text (see for example the most quoted chapter "Ulysses song”). In Levi's perspective literature assumes the essential task of dealing with the life of the camps. To recite poems becomes the means to fight 
- and hopefully defeat - the Nazi executioners' plan intended to humiliate and denigrate camp inmates. Literature is part of the cultural background of each individual and any memory, able to dig up part of that background, contributes to the recovery of the broken self: one's roots are preserved from oblivion and the Nazi plan is undone.

Levi himself reflects on the role of words in his account:

And then, for the first time, we became aware that our language lacked in words to express the offence, the demolition of a man. [...] They will deprive us even of the name: and if we want to preserve it, we should find in ourselves the strength to do it, in order to preserve a part of us, what we were, beyond that name. (Levi, I976, p. 23)

To perform any act of memory becomes the synonym of keeping one's identity safe.

\section{Tamiki Hara, Kore ga ningen na no desu}

The Japanese poet and novelist Tamiki Hara (原民喜, Hiroshima, November I 5, I905 - Tōkyō, March I3, I95 I) shared Levi's historical period but his fate was different. Hara was taken by surprise by the atomic bombing on Hiroshima in the morning of August 6, I945 and his literary production focuses mainly on the tragic experience as an hibakusha 被爆者 (a victim exposed to atomic bombing radiations). Extremely concerned about the employment of atomic bombs to resolve the US conflict with Korea in the I950s, he committed suicide by throwing himself on the railways between Kichijōji and Nishi-Ogikubo stations; an act defined by the Nobel Prize winner Kenzaburō Ōe as a "mute gesture of resistance" (Treat, I996, p. 74).

Hara was praised by the critic Kazuo Kuroko (I99I, p. 388) for being a spokesperson (kataribe 語り部 in Japanese) of the anti-nuclear and pacifist movements that had exploded throughout the nation during the aftermath of World War II. Hara echoed Levi in the galvanization of the sensitivity of public opinion. In particular, Hara's claim for the social awareness of the dangerous implications of the usage of nuclear energy with military purposes was always addressed to Japanese contemporary society as well as future generations; a belief the author frequently expressed 
through the words atarashii ningen e no kigan 「新しい人間への 祈願」 (“a plea towards new generations”; Hara, I949).

A sense of indignation can be perceived throughout the literary production of the author. Actually, the ikari no byōjō 怒りの 表情 (“expression of anger”; Kuroko, I99I, p. 386) detected by Kuroko is a common feeling shared by many hibakusha authors towards the Japanese government; a blend of resentment for the tragical occurrence of the Hiroshima and Nagasaki atomic bombings, along with the disillusion due to the Japanese surrender. This peculiar aspect should be considered as one of the differences between the testimonial approach to catastrophe shown by Hara and Levi. Tamiki Hara plays the role of the hibakusha author who lost, in a flash, any material ties with his homeland and, at the same time, he embodies the image of the betrayed and distrusted Japanese citizen who accused the government to be - at least partly - responsible for the national defeat in WWII.

Another difference with Levi, which is worth to mention, is the fact that Hara had already embraced a literary career when the atomic bombing of Hiroshima happened. The writer had been a professional poet and author of short stories since 1935 . The event of the atomic bombing did not represent for him the occasion for starting to write, but rather the main cause for a marked shift in his literary production, which after I945 was devoted only to the atomic bombing theme. Treat (I996, p. I67) writes that "Hara is also considered by many of those critics one of the founders of Japanese atomic-bomb poetry," alongside the genbaku shijin 原爆詩人 (“atomic bomb poet”) par excellence, Sankichi Tōge. ${ }^{9}$

In particular, the poems gathered in the collection Genbaku Shōkei『原爆小景』( “Little Atomic Scenery,” I950) offers a chance to reflect on the role of the literary testimony to portray the hibakusha experience. Among the nine poems classified according to a metonymic approach, the opening one stands for its unique content that is clearly reminiscent of Levi's Se questo è un uomo, resulting in the comparison between the two poetic

9 Tōge, Sankichi, born Mitsuyoshi (峠三吉, I9I7-I953) is considered the most important of these. 
productions which is at the core of this study. The title is Kore ga ningen na no desu「コレガ人間ナノデス」(“This is a human being”) and reads as follows:

This is a human being.

Please, have a look to the transfiguration due to the A-bomb.

The body is tremendously swollen

it changes man and woman in the same form.

Oh, from the tumid lips

burned face, illogically charred, a voice comes out:

"Help me please" feeble, silent words.

This, this is a human being.

The face of a human being. ${ }^{\text {Io }}$

A first remark should be made regarding the publication in which the poem appeared. Although chosen as the welcoming message for the collection of poems - a solution that mirrors the one of Levi - the literary work in question is not a testimonial account of his traumatic experience, like in the case on Levi's Se questo è un nomo. Eventually, Hara wrote a piece of work about his exposure to the atomic bombing of Hiroshima, the well-known Natsu no hana 『夏の花』( “Summer Flowers”) published in I947. In this brief testimonial account, which lasts only thirty pages, the author also added a poem, using the same stylistic choices as in Kore ga ningen na no desu. This shows a similar response to the trauma Levi and Hara respectively experienced, which points out the urge for the authors to express themselves in poetry as well as in prose.

Hara's Kore ga ningen na no desu belongs to the essay Sensō ni tsuite「戦争について」(“About War”) published for the first

г。コレガ人間ナノデス/原子爆弾二依ル変化ヨゴラン下サイ/肉体ガ恐ロ シク膨脹シ/男モ女モスベテ一ツノ型ニカヘル/オオ ソノ真黒焦ゲノ 滅茶苦茶ノ/爛レタ顔ノムクンダ唇カラ洩レテ来ル声ハ/「助ケテ下サ イ」/卜カ細イ 静カナ言葉/コレガ コレガ人間ナノデス/人間ノ 顔ナノデス;

Kore ga ningen nano desu/Genshi bakudan ni yoru benka wo goran kudasai/Nikutai ga osoroshiku bouchou shi/Otoko mo onna mo subete hitotsu no katachi ni kaeru/Oo sono makkura koge no mechakucha no/tadareta kao no mukunda kuchibiru kara moretekuru koe wa/"tasukete kudasai"/to kabosoi shizukana kotobalkore ga kore ga ningen nano desu/ningen no kao nano desu. 
time in the September issue of the Kindai Bungaku「近代文学」 ("Modern literature") magazine, I948. The main feature of the poem is the usage of the katakana phonetic syllabary combined with Japanese characters. ${ }^{\text {II }}$ At a first glance the graphical effect contributes to create an estrangement feeling in the reader, a sense of astonishment due to the reading of the challenging syllabary. But although today katakana's main use is the transliteration of foreign words, along with the need of highlighting brands, names, sounds (onomatopoeias), this syllabary was currently employed in official documents, together with the kanji ideographs, at least until the end of World War II. Its function was comparable to the role hiragana (Japanese phonetic alphabet) has today: even okurigana (the declensional kana ending) was normally written using katakana signs. If one considers the scholarly books of the time, usually written in kanji and katakana, the association of the two types of writing in poetry can also be interpreted as an attempt to render the poem more visible and readable to the general public. Similar observations have been made of Kenji Miyazawa's (宮沢 賢治, I896-1933) work, whose celebrated poems in katakana are even now subject of study. ${ }^{12}$

Hara's choice of katakana syllabary is thus anything but unique. However, nowadays any common Japanese-speaker may feel estranged by the cumbersome reading and this effect, although not deliberate, goes perfectly along with the contents of the poem, as to say, the description of a human being exposed to nuclear radiations. Eventually, Treat maintains that: "Hara's resort to $k a-$ takana makes the poem's lines reverberate with an urgency and intensity beyond what its contents alone can achieve" (Treat, I 996, p. I49). The lack of marks of punctuation and orthography, the choice of unconventional and unfamiliar terminology and the authorial tendency to leave verses incomplete, represent all features that contribute to the unnatural expressivity of the poem.

II This discussion about the katakana syllabary use in poetry represents the fulfilment of other dissertations on the same theme that I had the occasion to offer arguments for in other articles, see De Pieri, 2016 and De Pieri, 2017.

${ }^{12}$ For further investigation on the usage of katakana script and a critical bibliography, please refer to De Pieri, 20 I 8. 
In addition, it is outstanding to notice the skillful wording of the first and last verses that converge the attention of the reader on the hibakusha. A sort of "circularity" can be detected in these verses, which present to the world a victim exposed to radiations. Hara focuses the attention on the human being and emphasizes the subject of his poem repeatedly, as if pointing out that, although unrecognizable, those verses refer without doubt to a man or a woman. This also represents the core of Kore ga ningen na no desu: verses $3-8$ are dedicated only to the portrait of the victim. Transfigured, this body has no more gender: the atomic bomb has the atrocious power to deform the human condition to the extent that it also affects human reproductive ability. There is a subtle allusion beyond the line: the effects of radiation also undermine the health of future generations. The atomic bomb sickness known as genbakushō in Japanese is not a concern of the hibakusha of Hiroshima and Nagasaki only: it should be given universal attention for the scale of its harmful nature.

As Hara proceeds in his description, the reader is made aware of part of details about this burned and dying human. The estrangement created between what commonly is the image of a human being and Hara's verses is totally overwhelming and it leaves the reader startled. This is the product of what Treat called "dislocation of expectations" (I996, p. I 49): the reader feels dismay and rejection in front of what should be representing himself, a human being; but the hibakusha is furthest from looking like a human.

In the novel Michi『道』( “Streets", I985) by another hibakusha author, Kyōko Hayashi (林京子, I930-20I7), there is a dialogue between survivors of the Nagasaki atomic bombing. A professor Tanaka replies to the recent discovery of a colleague's corpse by emphasizing how the face plays a fundamental role in the recognition of a person. More than any other detail, it is the face who confirms the identity of people and this is why Hayashi, as the hibakusha kataribe par excellence, has always been putting so much efforts in restoring the identities of those acquaintances who lost their lives during the atomic bombing aftermath, to prove they once were alive. It is a literary production dedicated to the active testimony of hibakusha's experience, throughout her life. 
Similar observations were made by the journalist Yōko Ōta (大田洋子，1906-1963), victim of Hiroshima atomic bombing. Despite her literary commitment in reporting the real facts of what occurred during and after the atomic bombing of Hiroshima, her Shikabane no machi『屍の街』(“City of Corpses,” I948) underwent a strict censorship and was finally published only three years after its first draft in September I945; it remains the first testimonial account ever written on the theme, although not enough evaluated. She was probably the first one who enumerated the symptoms of the radiation sickness, with a keen eyesight and professional approach typical of the reporter. Among those, she located a state of apathy she addressed as muyoku ganbō 無欲願望 (Ōta, I948) a form of anhedonia (Krystal, I995, p. 80).

These references to other hibakusha authors serve to stress the importance of the hibakusha's face in Hara's verses, acutely inserted in the heart of the poem: that the nuclear weapon is responsible for the loss of the hibakusha's identity, seems to be revealed to the author. Even his voice gets lost: the oxymoron "silent words" (v. 8) stands for a craving for water (read: help), which is also a demand for recognition. The identity restoration means the recovery of the dignity of the victim. Notwithstanding, Hara makes the survivor's appearance incomprehensible to a non-hibakusha. His words are silent, his voice inaudible. Again, the author seems to tell more than what he writes: the meaning beyond the verses refers to the unique experience the hibakusha witnessed; something difficult to recount and maybe impossible to fully transpose into words. Hara is the spokesperson for the unspeakable and his audience the listener of the inaudible, thus, confirming the critical stance that only trauma victims can share the true understanding of the facts.

The grotesque portrait of the victim of radiation provoke aberration: the title of the poem, Kore ga ningen na no desu, should have been the promise for a loyal portrayal of human beings; instead, it turned into the abominable image of a hibakusha. There is no lyricism in Hara's poem; no rhetoric or lexical embellishment which can be perceived as the intentional attempt to aestheticize Hiroshima on August 6, I945. Like Levi's poem, the free verse allowed by the gendaishi ("modern poetry") appears 
as the most suitable solution to convey the physical and moral mourning of the hibakusha, frequently echoed by the alliterations. Reiko Tachibana points out that reiterations of nouns and vowels "seems to function to assure himself [Hara] of being alive" and that this stylistic choice "dramatizes his sense of shock and associates him with all sufferers" (I998, p. 6I). The technical-scientific matrix of the vocabulary Hara chose rather suggests authorial intent to be truthful to an objective description of the survivor and his sufferance.

\section{Conclusion}

The encounter with the Se questo è un uomo and Kore ga ningen na no desu poems offered an opportunity to reflect about the literary approach to human trauma. This brief analysis has detected some analogies and differences between the two poetic approaches to human annihilation, emphasizing in particular the common vision the authors shared about the disruption of the selfhood.

Both poems convey the need to give testimony to a traumatic event of a massive scale. The similarities are striking in the description of the victim, completely transformed by Lager life and radiation, to the extent that the human being is merely recognizable and deprived of any gender connotation.

Both authors turn their poems into the welcoming message of their literary works, prose and poetry respectively; this literary experimentation underlines the search for the best means possible to convey their traumatic testimonies.

Concerning the literary and stylistic solutions adopted by the authors, I noted that Hara was a professional author before I945, while Levi was a chemist. One would expect this difference to be mirrored in the diverse authorial choices in style, but this is not the case. Levi appears more concerned about the artistic value of his production as shown by the occurrence of rhetorical and metaphorical figures. Hara, on the contrary, opts for a vocabulary selected from the scientific field, as if to prove that the atomic bombings do not allow any aesthetic representation of the hibakusha. His lexical choice also strengthens the contradiction between the scientific progress, represented by the atomic weapons, and 
the effects this scientific development caused on humankind. Levi's choice would be the natural response for a man keen in literature and the classics, since his commitment as survivor of the Shoah would prevent him in any attempt to aesthetically embellish his experience.

Both authors show a preference for free verse, which fosters the incrementation of their expressiveness, while the choice of the harsh terminology enables them to create distance between the subject of the poem - and the author himself - and the reader.

The authors address the audience directly. According to Tachibana "Hara's protest seems to be directed more generally toward the 'absurdity of humankind" (I998, p. 63). His feelings of resentment and anger are not shared by Levi, although the author stated that he would never forgive (read: accept) the culprits, at least unless they show a serious awareness of their sins (Levi, I976, p. I 59). His authoritative tone forces the readers' attention to the truth disguised in the historical reports of the Shoah and urges the public to give testimony and perpetuate Häftlinge memories.

Hara's approach is softer and turns politely the attention of the audience to the hibakusha portrait ("Please, have a look", v. 2), perhaps conscious that the gap between the different register contributes to the estrangement feeling of discomfort of the poetry, a similar uneasiness perceived even in Levi's Se questo è un uomo. In Kore ga ningen na no desu, this unpleasant sensation is stressed by the uncommon usage of the katakana syllabary, which assumes for a contemporary reader an unfamiliar connotation in poetry, although accepted in Japanese modern poetry. While Levi's verses seem to share Auschwitz experience with the readers, Hara's poem is circular, as to suggest that what the bibakusha experienced is neither sharable, nor understandable. This perception is detectable even in Levi's production, although the author makes any effort to accustom the language in order to reach a wider audience.

Primo Levi reminds us of the great responsibility of the reader: to receive his testimony, to preserve it and perpetuate it to future generations. In the appendix of Se questo è un uomo, the author explains: "Only then the witness accomplishes his duty, which is to pave the way for the judge. The judge is you." (Levi, I976, 
p. I 57). This is a challenging task that involves the efforts of both victims and non-victims, together against the conniving omertà ("silence") intended to obliterate history. In this sense, even though silence can often speak louder than words, it can also be perceived as a Hitlerian victory: if you are a speechless survivor, the possibility to recover and restore your self-identity becomes more troublesome, because the experience itself is felt as extraneous, totally unfamiliar and alien to the personhood. Memory and oblivion become then the double faces of the same coin. "To construct and preserve Auschwitz memory means for Levi to try giving a sense to that experience" (Sullam, 20I0, p. I05). According to the author the value of testimony resides in its educative performance, not as a political controversy, religious sermon, or social critique. Levi's literary production functions as "artificial memory" (Levi, I976, p. I77) to stimulate the audience's response. However, with "artificial" Levi does not mean imaginative or fictional: "Because the theme of the massacre is not open to revision and fiction. The few novels written on the topic are odious, they are disgusting to read.” (Levi quoted by Sullam, 20I0, p. Iо8)

The refusal of any fictive production does not deny an authorial attempt to elaborate and process memories in order to convey them in a revised literary form; as noticed in this brief study, despite of the seriousness of the theme touched by the author, his poem is steeped in a lyricism that actually enables the reader to sympathize with the Häftlinge. Levi's stance is rather addressed merely to fictional products: only the documentary novel is considered the loyal testimonial account of the facts.

The literary production on the atomic bombings seems, by its very nature, to agree with Levi's viewpoint. The nuclear weapon itself is ambiguous because it celebrates the technological progress of humankind, but it is, at the same time, aimed for human annihilation. Only documentary works like historical reports, scientific inquiry and survival's journals and diaries are acceptable as testimonies of these atrocities. The language implied to bear those memories is as detailed and deprived by baubles as possible. "That moment of 'forgetting' permitted by metaphor is a moment that lets one be ignorant at the same time" (Treat, I996, p. I66). To forget is even more inaccessible to hibakusha because 
they are forced to live everyday with the fear that the symptoms of the genbakushō could appear; an anxiety well reframed by Kyōko Hayashi's words "Everyday is August, 9," referring to the atomic bombing of Nagasaki.

To conclude, Levi's Se questo è un uomo and Hara's Kore ga ningen na no desu are remarkable examples of how effective testimonial literature can be to transpose into a universal language the individual trauma of the survivors and, in doing so, in going beyond any boundaries: national (Italy/Japan), historical (Nazi's deportation/atomic bombings), traumatic (status of Häftlinge/ hibakusha) boundaries are subdued to the imperative to give testimony of the brutal consequences of humanity in extremis. A comparative reading of these literary products reveals how, even though those atrocities were meant to divide human beings, they rather enable a mutual understanding of individual trauma, thus transforming it to a value that is a collective one, thanks to a metonymic transposition of human suffering. Hence, the therapeutic value of this testimonial narrative should not be underestimated. Leveraging human empathy in the wake of catastrophe, literature reveals once more its persuasive power to re-connect and reestablished human bonds by re-constructing both individual and collective identity.

\section{References}

Adorno, T. (I955). Prismen. Kulturkritik und Gesellschaft. Berlin: Suhrkamp Verlag.

Angress, W. T., Cooper, B., Schoenberner, G., \& Schoenberner, M. (2002). The Wannsee Conference and the Genocide of the European Jews: Guide and Reader to the Permanent Exhibit in the House of the Wannsee Conference. Berlin: House of the Wannsee Conference Memorial and Educational Site.

Caruth, C. (1995). Trauma, Exploration in Memory. Baltimore: Johns Hopkins University Press.

Dante, A. (I32I). “Inferno, Canto III," in Commedia. Firenze.

Dayton, T. (2000). Trauma and Addiction. Ending the Cycle of Pain through Emotional Literacy. Florida: Health Communications Inc. Publishing. 
De Pieri, V. (20I6). "Wagō Ryōichi’s Net-Poetry and the Revolutionary 'Shared Literature'," in Annali. Venice: Ca' Foscari University.

- (2017). "Wagō Ryōichi's Net-Poetry: Tradition and Innovation," in Conference Proceedings of the Ist International Conference Comparative Studies of Language and Culture Tradition and Innovation. Poznań: Adam Mickiewicz University.

- (2018). "New Media Communication and Net-Poetry: The Uses of Katakana Script in the Aftermath of the Triple Disaster in Japan," in EAJS International Conference 2017 Proceedings. Lisbon: EAJS Publishing.

Desmond, G. (I998). Poetry of The Second World War. London: Pimlico.

Hara, T. (I947). Natsu no hana. Tōkyō: Mitaka Bungaku zasshi.

—_ (I948). "Sensō ni tsuite," Aozora Bunko: July 20, 2002. Available at: http://www.aozora.gr.jp/cards/000293/files/4785_6740 .html, (Accessed: I I June 20I2).

__ (I949). "Shi to ai to kodoku," Aozora Bunko: July 20, 2002. Available at: http://www.aozora.gr.jp/cards/000293/files/4772 _6670.html, (Accessed: I I June 20I2).

—_ (I950). "Genbaku Shōkei," in Kindai Bungaku August issue. Tōkyō: Kindaibungakusha.

Kuroko, K. (I99I). "Genbaku to kotoba," in Odagiri H. (ed.) Genshiryoku to bungakusho. Hara Tamiki kara Hayashi Kyōko made. Tōkyō: Tōkyō Nihon Tosho sentā.

Krystal, H. (I995). "Trauma and Raging: A Thirty-Year Follow up," in Cauth, C. (ed.) Trauma, Exploration in Memory. Baltimore: Johns Hopkins University Press.

LaCapra, D. (200I). Writing History, Writing Trauma. Baltimore: The Johns Hopkins University Press.

Lemkin, R. ( I946). “Le crime de génocide: June I 6 2000.” Available at: http://www.preventgenocide.org/fr/lemkin/legenocideI946.htm, (Accessed: 25 June 2017).

Levi, P. (1975). L'Osteria di Brema. Milano: All'insegna del pesce d'oro.

(1976). Se questo è un nomo. Torino: Einaudi. 
Ōta, Y. (I948). Shikabane no machi. Tōkyō: Chūoukōronsha.

Segre, C. (1976). "Auschwitz, orribile laboratorio sociale," in Se questo è un uomo. Torino: Einaudi.

Sullam, S. L. (2010). "Elie Wiesel e Primo Levi, memorie divise di Auschwitz," in Oltre la Notte. Memoria della Shoab e diritti umani. In occasione degli 80 anni di Elie Wiesel. Firenze: Giuntina.

Tachibana, R. (1998). Narrative as Counter-Memory: A HalfCentury of Postwar Writing in Germany and Japan. New York: State University of New York Press.

Treat, J. W. (1996). Writing Ground Zero: Japanese Literature and the Atomic Bomb. Chicago: University of Chicago Press.

Young, J. (2003). "Between History and Memory: The Voice of the Eyewitness," in Douglass, A. and Vogler, T. (eds.) Witness and Memory. The Discourse of Trauma. London: Routledge, p. 275-285. 